\title{
De las alturas maníaco-depresivas a las superficies de la perversión: la imagen deleuziana del filósofo*
}

\author{
From manic-depressive heights to the surface of perversion: \\ a deleuzian image of the philosopher
}

VALERIA SONNA**

\begin{abstract}
Resumen: Deleuze opone una imagen cínicoestoica del filósofo de las superficies, que describe la filosofía como un movimiento de perversión, a la imagen platónica del filósofo de la alturas, que describe la filosofía como un movimiento maníaco-depresivo. Nuestro objetivo es mostrar que, si bien su lectura aborda la filosofía platónica desde una perspectiva actual, ello no va en desmedro de su precisión histórica que enfatiza aspectos novedosos de temas clásicos.

Palabras clave: Estoicismo, Cinismo, Inversión del platonismo, Teoría de los incorporales.
\end{abstract}

\begin{abstract}
Deleuze opposes a Stoic-Cynic image of the philosopher of the surfaces, which describes philosophy as movement of perversion, to the platonic image of the philosopher of altitudes, which describes philosophy as a manic-depressive movement. We aim to demonstrate that even though his interpretation reads Platonism from a contemporary point of view, this does not hinder its historical accuracy, which emphasizes novel aspects of classical topics.
\end{abstract}

Key words: Stoicism, Cynism, Reversal of Platonism, Theory of incorporeals.

\section{Introducción}

Existe una tensión entre filosofía e historia de la filosofía que lleva a que el problema del anacronismo se plantee como una dicotomía: o bien leemos las filosofías del pasado para hacerlas relevantes para nuestros problemas contemporáneos --transmutándolas para que se

Recibido: 02/06/2017. Aceptado: 16/02/2018.

* Este trabajo es parte de mi proyecto de Doctorado, financiado con una Beca del Consejo Nacional de Investigaciones Científicas y Técnicas (CONICET).

** Doctora en Filosofía por la Universidad de Buenos Aires (UBA), docente de la Carrera de Filosofía de la Universidad Nacional de San Martín (UNSAM), docente de la Carrera de Filosofía de la Universidad de Ciencias Empresariales y Sociales (UCES), Becaria Posdoctoral del Consejo Nacional de Investigaciones Científicas y Técnicas (CONICET). Publicaciones recientes: Sonna, V. (2018), "La inversión del platonismo en la obra de Gilles Deleuze” en Diánoia e-I SSN 1870-4913; Sonna, V. (2017) “ouk éstin antilégein: Antístenes tras la máscara de Parménides en el Sofista de Platón” en Eidos, Nro. 26, enero-junio 2017, e-ISSN: 2011-7477. E-mail: vsonna@gmail.com 
acerquen a lo que serían si fueran parte de la filosofía de hoy y minimizando, o ignorando, aquello que se resiste a esa transmutación-, o bien tomamos la cuidada precaución de leerlas en sus propios términos tratando de preservar su idiosincrasia y carácter específico de manera que no puedan emerger en el presente sino como piezas de museo (Macintyre, 1984).

Quienes sostienen que la historia de la filosofía es, ante todo, un estudio histórico priorizan los criterios de imparcialidad, fidelidad a los textos y la objetividad del método. Esta exigencia supone el cuidado de no incorporar en la exégesis de los textos categorías ajenas a la época (Brunschwig, 1992). Quienes sostienen que la historia de la filosofía es, ante todo, filosofía priorizan la función filosófica de los textos desde la cual la apropiación de las fuentes sirve para pensar los problemas actuales (Aubenque, 1992).

Este debate tiene una especial actualidad en el ámbito de la historia de la filosofía antigua en el que los criterios filológicos e historiográficos a veces terminan por predominar sobre otros de corte más filosófico como la libre interpretación y la reapropiación de los conceptos. Quizás en parte debido a esto es que se ha sentido a veces la necesidad de justificar la relevancia del estudio de la filosofía antigua. Boeri, por ejemplo, afirma que la actualidad de la filosofía antigua radica tanto en los problemas que los filósofos clásicos tematizan, los cuales son retomados por la filosofía de épocas posteriores, como en la metodología de la que se valen para pensar (Boeri, 2000). Según W. Wieland, la tensión entre el presente y el pasado es constitutiva de la conciencia histórica y no puede ser neutralizada. Es de suma importancia tener en cuenta que la filosofía contemporánea, en sus casos más significativos, ha llegado a sus resultados por vía de la recepción, crítica y confrontación con el pensamiento antiguo (tal es el caso por ejemplo de Hegel, Heidegger, Whitehead, Ryle, Gadamer y Popper). En este punto el aseguramiento filológico e histórico es un presupuesto necesario pero no suficiente. La investigación erudita de la filosofía antigua pone de manifiesto sólo uno de los múltiples aspectos desde los cuales puede ser considerada su actualidad que depende tanto de una perspectiva histórica como de una perspectiva crítica (Wieland, 1988, 1-4).

En este panorama, la lectura que Deleuze tiene de la filosofía antigua nos interesa, no sólo por su carácter crítico, sino también por el uso que hace de ella en vinculación con los problemas de la filosofía actual. F. Wolff sostiene que la aproximación de Deleuze a los textos antiguos debe pensarse en función de tres lineamientos que comparte con Derrida y con Foucault. En primer lugar, que la Grecia de estos autores está compuesta exclusivamente de textos, con poco espacio para sus instituciones políticas o sociales, sus producciones estéticas y su historia. Textos que son, además, fundamentalmente teóricos, es decir, textos que se proponen enunciar verdades. Pero estos textos no son considerados por ellos como portadores de enunciados asertóricos y que, por lo tanto, han de ser leídos, interrogados y discutidos en función de la verdad a la que aspiran; sino como textos a interrogar en cuanto a su sentido y a leer en cuanto a lo que manifiestan a pesar de sí. Wolff afirma que Deleuze, al igual que Foucault y Derrida, privilegia el corpus de la obra platónica en muchos aspectos. En primer lugar, aceptan el mismo presupuesto según el cual la filosofía, y particularmente la filosofía griega, no solo está en la historia, no solo tiene una historia, sino que es una historia. Pero además, dicha historia se inscribe en un relato cuyo primer capítulo sería "esto empieza con Platón" y el último, que el platonismo se acaba al invertirse.

A los ojos de Wolff, Deleuze es el menos suspicaz de estos tres filósofos, dado que lee los textos como portadores de enunciados aceptables, animados todavía por un proceder en 
cierto sentido fecundo y no solamente como significativos o sintomáticos. En esta línea se enmarca la hipótesis del presente trabajo. Deleuze sostiene que la imagen del filósofo que heredamos del platonismo ocupa un lugar preponderante en la concepción de lo que significa pensar en la tradición filosófica y que el problema es que ésta nos encierra en una concepción abstracta de lo que significa filosofar. Nuestro objetivo es poner a dialogar la lectura deleuziana con los estudios clásicos para mostrar se trata de una lectura filosófica pero también histórica. Es filosófica, porque se preocupa por las consecuencias que la filosofía platónica tiene sobre el pensamiento hoy, pero también es histórica, puesto que, si bien no se vale de herramientas filológicas para el análisis de las fuentes, reconstruye de manera adecuada los sistemas filosóficos que aborda.

\section{Las tres imágenes del filósofo}

Isabelle Ginoux afirma que la pregunta-problema deleuziana de Lógica del sentido es la pregunta "¿quién habla en la filosofía?" y que la respuesta está determinada en función de criterios topológicos (Ginoux, 2005, 155). Ginoux se refiere al criterio que Deleuze utiliza para clasificar las tres imágenes del filósofo que encuentra en el período de la filosofía grecolatina, a saber, la imagen platónica que orienta la mirada del filósofo hacia arriba, la imagen presocrática que orienta la mirada del filósofo hacia abajo y la de los cínicos y estoicos que la sostiene en la superficie $(1969,155)$. Nos interesa agregar que además del criterio topológico, Deleuze agrega lo que podríamos llamar un criterio nosológico. Cada una de las direcciones de la mirada filosófica queda asociada a una enfermedad de la psiquis: las alturas platónicas con el síndrome maníaco-depresivo, las profundidades presocráticas con la esquizofrenia y las superficies cínico-estoicas con la perversión.

El pensamiento tiene, para Deleuze, ejes y orientaciones según las cuales se desarrolla, "tiene una geografía antes de tener una historia. Traza dimensiones antes de construir sistemas" $(1969,152)$. La pregunta principal que se formula es "¿qué significa orientarse en el pensamiento?". El gran Oriente que descubre en Platón es el cielo de la ley moral. Deleuze sostiene que la imagen del filósofo, tanto la popular como la científica, ha sido establecida por el platonismo. Ésta es la del filósofo como un ser de las alturas, que sale de la caverna y se eleva, a la vez que se purifica mientras más se eleva $(1969,152)$. Un psiquismo ascensional que ha marcado la imagen del filósofo y la topología del pensamiento y del cual el cliché de Tales de Mileto como el filósofo en las nubes que se distrae de lo que ocurre en la tierra por tener su mirada puesta en el cielo también es parte. La imagen del cielo teórico del filósofo que lo aleja de las leyes de la tierra.

Deleuze encuentra una imagen alternativa a la del cliché de las alturas en la filosofía de Nietzsche. En contraposición al platonismo, dice Deleuze, Nietzsche toma la imagen del filósofo presocrático, el de las profundidades de phúsis. La diferencia fundamental consiste en que, desde las alturas platónicas, el filósofo pretende que la medida y la proporción, es decir, la ley tanto moral como física, venga dada desde afuera, desde la trascendencia; mientras que desde las profundidades presocráticas, el filósofo busca la ley en las profundidades de la phúsis: el orden de un cosmos que responde a regularidades naturales.

Deleuze también hace lo propio, y forja una imagen diferente. Ni las alturas platónicas, ni las profundidades de Nietzsche y los presocráticos, sino las superficies. La imagen del 
filósofo que se desliza por las superficies la extrae también de los griegos, apropiándose de las filosofías cínica y estoica. Le agradan especialmente las anécdotas de Diógenes y de Crisipo, el uno desafiando la moral establecida con su conducta, el otro desafiando la posición de maestro negándose a responder o respondiendo con ambigüedades. Veamos entonces cómo describe Deleuze estos tópoi.

\section{Las alturas platónicas}

La altura es el Oriente propiamente platónico y la consiguiente operación del filósofo es la ascensión. Esta metáfora de la que se vale Deleuze tiene muchos niveles de lectura. En primer lugar, la orientación hacia arriba es símbolo de la hipóstasis de la Idea y de la creación de un plano de trascendencia donde residen los principios que regulan la existencia y el proceso mediante el cuál conocemos y pensamos el mundo a nuestro alrededor. En segundo lugar, implica un alejamiento de lo corporal en pos de un mundo incorpóreo, sin el peso de la materia. De allí la metáfora del ascenso. Este ascenso queda asociado también a un ascetismo que Deleuze identifica con el mecanismo que consiste en alejar el pensamiento del páthos en virtud del lógos. Este proceso va acompañado necesariamente según Deleuze, de una conversión: "el movimiento de volverse hacia el principio superior del que él [el pensador] procede y de determinarse, llenarse y conocerse desde tal moción" $(1969,152)$.

El idealismo es, dice Deleuze, la enfermedad congénita de la filosofía platónica y, con su cadena de ascensiones y caídas, es la forma maníaco-depresiva de la filosofía misma. La referencia principal de Deleuze en torno a este problema es la alegoría de la caverna de República VII. Esta es parte de una trilogía de tres alegorías que incluye también la del sol y la de la línea, las cuales son parte fundamental del relato del ascenso del filósofo y están presupuestas en su narración. En estos libros está contenido el desarrollo de la posición epistemológica y metafísica que es fundamental a la problemática de todo el texto de República. ${ }^{l}$ En este texto platónico, en efecto, el principio regulador, a saber, la Idea del Bien, está ubicada "arriba", mediante la analogía con el sol. La alegoría del sol sostiene argumentativamente la postulación de la Idea del Bien como principio del conocimiento superior. La analogía supone un paralelo entre dos tópoi: el de lo inteligible (en tô noêtô) y el de lo visible (en tô horatố). El sol no es la vista misma pero es causa - en el sentido de que es responsable (aítios) - de la vista, como el Bien es causa de la inteligencia (noús) (508b-c). El Bien, además de ser causa es también principio porque, al igual que la vista y la luz no son el sol sino que el sol es algo distinto, de la misma manera, el conocimiento y la verdad no son el bien mismo, sino que este es algo distinto. El Sol es distinto de la luz y la vista porque es su condición de posibilidad; de la misma manera, el Bien es condición de posibilidad de la verdad y el conocimiento (508e-509 a). El Bien es principio epistémico, pero a su vez es también principio ontológico: las cosas no son solo cognoscibles en virtud del Bien, sino que también su existencia y su realidad (tó eînai te kaì tền ousían) les viene de él "aunque el Bien no sea ousía sino algo que está más allá de la ousía (509b).

Esta analogía está supuesta luego en la alegoría de la Línea que tiene como función el establecer las diferencias entre los cuatro procesos cognitivos, eíkasía, pístis, diánoia y nóesis

1 Nos basamos en la edición de Burnet (1902) y en la traducción de Mársico \& Divenosa (2005) 
o epistéme. Una vez planteadas la analogía del Bien y el Sol y la alegoría de la Línea, el relato de la caverna plantea esta distribución del pensamiento en términos de sus consecuencias éticas en relación a la función del filósofo en la sociedad. La alegoría de la caverna describe una escena en la que un grupo de hombres están encadenados de manera tal que no pueden ver sino hacia adelante. En frente tienen un gran muro en el que ven solo simulacros, que son los reflejos de las sombras que allí se proyectan. A sus espaldas hay otro muro detrás del cual un gran fuego ilumina a otros hombres que transitan acarreando objetos. Son las sombras de estos objetos las que ven los encadenados. Más atrás del muro se eleva un camino que lleva a la salida de la caverna en la que se encuentran estos hombres. Un día uno de los encadenados es liberado y sube por el camino hacia afuera de la caverna. Este relato anuda la idea de ascenso con la de liberación, aquí tenemos al filósofo que tras liberarse debe iniciar una ascensión (anábasis), y sólo entonces comienza a ver realmente (514 a-516b).

Los simulacros o sombras corresponden a los correlatos de la eikasía, mientras que los objetos acarreados por los hombres que transitan la caverna por detrás de los encadenados se corresponden con los correlatos de la pístis. Lo que caracteriza el estado epistémico de los encadenados, la eikasía, es el estado de ensueño, que es equiparable también al olvido y a la ignorancia. La idea que presenta Platón a través de este relato es la de la pedagogía como un arte de reorientación o reconducción (periagogệ) del alma. La educación sirve para alterar la orientación previa (518d). Esta orientación de la mirada queda expresada, no sólo por el haber establecido la anábasis como proceso de liberación del pensamiento, sino también por la elección del léxico que Platón usa para referir a la mirada del que mira después de haber sido liberado. En 515e Platón dice el liberado, cuando se encuentra con la luz del sol, como primer impulso tiende a volver a mirar hacia las cosas que puede "ver hacia abajo". En 516a, las sombras (skiás) y los simulacros (eídolon) se "miran hacia abajo". El verbo en griego es kathoráo, que significa "mirar de arriba", o lo que es lo mismo, desde el lugar del verdadero mirar, el lugar del conocimiento.

Este juego conceptual que Platón establece por medio del uso alegórico de los tópoi, identificando el arriba con el plano noético y el abajo con el plano sensible, así como la alusión terminológica - mediante el uso del verbo kathoráo - al lugar donde el pensador debe instalar la mirada, ya que es el lugar de la verdadera visión, concuerda con el "diagnóstico" deleuziano del ascensionismo psíquico. Pero también, dado que el proceso pedagógico requiere el regreso a la caverna, es decir, el bajar nuevamente al plano sensible y al plano de las sombras, también concuerda con el diagnóstico maníaco-depresivo que Deleuze equipara con el movimiento platónico del pensamiento en la filosofía. Veamos ahora cómo opera la mirada que se instala en las profundidades.

\section{Las profundidades presocráticas}

Deleuze sostiene que Nietzsche invierte el Oriente platónico porque encuentra la verdadera orientación de la filosofía en las profundidades y descubre en la filosofía presocrática la filosofía por venir. Deleuze encuentra en este gesto nietzscheano un movimiento que surge de las profundidades y que se opone al movimiento que se eleva hacia las alturas. Y, así como caracteriza a la pedagogía platónica como un movimiento maníaco-depresivo, describe las profundidades que emergen en el presocratismo como la esquizofrenia pro- 
piamente filosófica. Es, dice, "la profundidad absoluta que ahonda en los cuerpos y en el pensamiento" $(1969,153)$.

La lectura de Deleuze tiene base en la figura de Empédocles, pensador que inspiró a Nietzsche y, antes que él, a Hölderlin. Para expresar "las profundidades" como topología, Deleuze se inspira en la anécdota relatada por Diógenes Laercio según la cual Empédocles murió al caer en un volcán, quedando de él solamente una sandalia (VIII, 63). Encuentra aquí un buen contrapunto de las alas platónicas: la sandalia de Empédocles que emerge de las profundidades. Así como la conversión le parece la manera platónica de la orientación, encuentra la subversión como forma de la orientación presocrática.

Deleuze describe el sistema de Empédocles como una alternancia entre "el cuerpo del odio", que describe como el cuerpo troceado; y "el cuerpo glorioso", que describe como el "cuerpo sin órganos" que conforma una sola gran pieza, sin miembros, sin voz y sin sexo.

Recordemos que son dos los principios que rigen en la filosofía de Empédocles: la integración y la desintegración del cosmos, Phílos (el amor) y Neîkos (la discordia). Phílos es el principio de cohesión por el cual los seres se funden en la unidad pasando de ser múltiples y diversas a ser una unidad. Esta unidad total es la que Deleuze identifica con su propio concepto de "cuerpo sin órganos". El cuerpo sin órganos es un concepto cuya característica principal es que se opone a los objetos parciales y a la organización de órganos, es decir, el cuerpo biológico. Pero también se opone al cuerpo social en tanto organización ${ }^{2}$.

Por otro lado, Nê̂kos es el principio por el cual los seres se separan y pasan de la unidad a la diversidad (Fr. 348). ${ }^{3}$ Deleuze asocia el principio de desintegración con las características de la esquizofrenia, ${ }^{4}$ cuyo trastorno fundamental es la disociación. La lectura de Deleuze es literal. El término está compuesto skhizo, verbo que significa "dividir" o "separar" y phrén que significa "mente". Deleuze encuentra en Nê̂kos el locus de la escisión que propone metonímicamente como descripción del movimiento.

Deleuze se apropia del gesto nietzscheano y elige el tópos que a su criterio describe de mejor manera la orientación que debe tener el pensamiento: las superficies. Elije para ello la imagen inspirada en los cínicos y los estoicos ${ }^{5}$, del filósofo que transita los espacios públicos cuestionando las costumbres de los ciudadanos mediante el recurso de la perplejidad y la sorpresa.

\section{Las superficies cínicas}

Deleuze opone la perversión cínico-estoica a la conversión platónica y a la subversión presocrática $(1969,158)$. Este “extraño arte de las superficies” implica un desplazamiento,

2 Este concepto no presenta todavía en Lógica del sentido la complejidad que tendrá en AntiEdipo. Sobre la evolución de este concepto véase Zourabichvili (2003, 15-17).

3 [= Simpl. In Phys. 158,1] Nos basamos en la edición de Kirk, Reven, Schofield, (1957)

4 Esta categoría nosológica juega en este texto un rol diferente del que juega en el Anti-Edipo donde funciona como figura del deseo y límite del capitalismo.

5 Si bien Deleuze comienza diciendo que la imagen del filósofo de las superficies está marcada por las filosofías cínica, estoica y megárica, en rigor sólo se refiere en el desarrollo que hace de este problema, a los cínicos y los estoicos. Propone para este tercer tópos una imagen del filósofo forjada sobre Crisipo de Solos, de la escuela estoica y Diógenes el Cínico. 
indicado por el prefijo indoeuropeo - per que indica un tránsito a través de. Como veremos, este desplazamiento es llevado a cabo, por un lado, mediante la crítica cínica a los valores de la época pero también mediante la inversión estoica del platonismo.

La perversión, desde el punto de vista psicoanalítico, consiste en la desviación del placer sexual, lo cual se adecua, como veremos, al tenor de las anécdotas narradas por Diógenes Laercio. ${ }^{6}$ Pero además, etimológicamente, la palabra remite al trastocamiento y al desorden y, más aún, a la destrucción. Es, justamente, el trastocamiento del orden moral, su inversión, a lo que apunta la crítica performática que Diógenes y Crisipo llevarán adelante.

Diógenes de Sínope fue un pensador que vivió entre el 404 y el 323 a.C. aproximadamente. ${ }^{7}$ Según los testimonios, su padre, quien tenía a cargo la banca de Sínope, falsificó la moneda, siendo así desterrado junto a su familia. Según Laercio es así que Diógenes llegó a Atenas, donde conoció a Antístenes, de quien se dice que es el iniciador de la escuela cínica, y se convirtió en su discípulo. ${ }^{8}$ Diógenes fue famoso por invertir los valores de su época; por promover, haciendo un ejemplo de sí mismo mediante su conducta, una moral diferente. Quienes dudan de la historicidad de la anécdota de la moneda sostienen que puede ser esta modalidad de Diógenes como pensador la que haya dado lugar a la leyenda. Se adjudica a su padre (o a él, según las distintas versiones) el "falsificar la moneda", en griego "parakharáttein tò nómisma", pero en esta expresión - que estaría extraída del Pórdalos, uno de los textos atribuidos a Diógenes - "nómisma" podría hacer referencia a las costumbres y no a la moneda. En tanto Diógenes oponía las necesidades naturales a los hábitos superfluos de los hombres, re-valoraría (parakharásso) las costumbres (Giannantoni, 1990, 423-432).

A diferencia de Platón, que escribía diálogos, o de los sofistas que escribieron tratados, Diógenes fue ejemplo viviente de su filosofía, , "un actor comprometido que ofreció a sus contemporáneos una verdadera performance, un ejemplo a seguir, ejemplo directo, sin recurrir a un texto como intermediario" (Cordero, 2013, 34). Fue además un provocador, al igual que lo fueron sus discípulos y también Antístenes. Sostenía una vida en extremo austera, condenando de esta manera la riqueza material y la pobreza espiritual. Dormía en toneles en espacios públicos y vestía siempre una túnica rotosa con un morral y un bastón (Diógenes Laercio, VI, 23). Promovía con su conducta una moral ascética. Cuenta Laercio que en el verano se echaba a rodar sobre la arena ardiente y en invierno se abrazaba a las estatuas heladas por la nieve, diciendo que de esta manera se acostumbraba a todos los rigores e inclemencias (ídem). Despreciaba las riquezas y a los hombres ávidos de ellas, decía

6 El diccionario de La Planche \& Pontalis J. B. (1996) sostiene que hay perversión "cuando el orgasmo se subordina imperiosamente a ciertas condiciones extrínsecas (fetichismo, transvestismo, voyeurismo y exhibicionismo, sadomasoquismo); éstas pueden incluso proporcionar por sí solasel placer sexual. De un modo más general, se designa como perversión el conjunto del comportamiento psicosexual que acompaña a tales atipias en la obtención del placer sexual".

7 Si bien hay dudas sobre la exactitud de estas fechas, las especulaciones dan un margen de error de no más de 10 años, Cf. Giannantoni (1990, IV:421-423).

8 Ha sido puesto en duda que Diógenes haya tenido un vínculo de este tipo con Antístenes, e incluso que haya habido una sucesión sin solución de continuidad entre Antístenes, los cínicos y los estoicos, como lo sugiere Laercio (Giannantoni, 1990: IV, 223-233; 1991, 15-35) Sin embargo, a los fines de lo que nos interesa destacar aquí, hay una línea de continuidad que aunque no esté marcada por la sucesión discipular, sí lo está por el carácter provocador y por el sobrio ascetismo que define a estos pensadores.

9 Acerca del pensamiento politico y la obra escrita de Diógenes véase Dorandi (1991). 
que los dioses habían concedido a los hombres una existencia fácil, pero que ellos mismos se la habían ensombrecido al requerir pasteles de miel, ungüentos perfumados y cosas por el estilo (VI, 44). Llevaba una vida pobre, decía que todas las maldiciones de la tragedia habían caído sobre él, que siempre estaba sin hogar, exiliado y muerto para su patria. Decía de sí mismo que era un vagabundo que rogaba por el pan día a día. Pero afirmaba que a la fortuna él oponía el coraje; a la convención, la naturaleza; a la pasión, la razón. Una vez que yacía al sol en el Craneo, Alejandro Magno le dijo: "pídeme lo que quieras", a lo que él contestó: "quítate que me haces sombra" (VI, 38). Del mismo modo rechazó a Crátero cuando lo invitó a acudir a su corte porque prefería "lamer sal en Atenas que disfrutar de la espléndida mesa en el palacio de Crátero" (VI, 51). Desdeñaba los encomios y llamaba al vientre "Caribdis de la existencia"(ídem).

La pedagogía cínica consiste en provocar e inquietar. ${ }^{10}$ La provocación es la estrategia para invitar a filosofar y generar inquietud es la manera de incitar a la filosofía. Diógenes desplegaba distintas estrategias para llamar la atención de los jóvenes y así atraer discípulos, algunas de ellas son descriptas por Diógenes Laercio, como la que cuenta que una vez se puso a comer legumbres enfrente de un joven que pronunciaba un discurso muy metódico y formal (VI, 48), o la que relata que se paró frente a una estatua para pedirle limosna (VI, 49). Acritudes éstas que, según Cordero (2013), estaban dirigidas a atraer discípulos llamándoles la atención.

Su crítica a la sociedad y a los distintos sistemas filosóficos eran también performáticas. Diógenes ponía en cuestión los valores y costumbres mediante su perversión. Llevaba su conducta ascética al extremo, comía, dormía y se masturbaba en lugares públicos (VI, 46, 69); también entraba al teatro por la puerta de salida y salía por la de entrada sosteniendo que esto era lo que trataba de hacer durante toda su vida (VI, 64). Diógenes Laercio relata que conversaba sobre el goce y el placer y los ponía en práctica abiertamente, "troquelando con nuevo cuño lo convencional de un modo auténtico, sin hacer ninguna concesión a las convenciones de la ley, sino sólo a los preceptos de la naturaleza, afirmando que mantenía el mismo género de vida que Heracles, sin preferir nada a la libertad" (VI, 71). Su moral era rígida y su austeridad extrema. En un viaje a Egina fue capturado por piratas y luego puesto a la venta en Creta. Se dice que cuando le preguntaron qué sabía hacer contestó que sólo sabía gobernar hombres. Finalmente tuvo suerte y lo compró Jeníades, en cuya casa se dice que pasó el resto de sus días como educador. Educó a sus hijos y además de enseñarles obras de poetas y prosistas les enseñó a cuidarse alimentándose de manera sencilla y bebiendo sólo agua. Les hacía usar el pelo rapado y sin adornos y los acostumbró a andar sin calzado (VI, 29, 30, 31, 74).

Las críticas de Diógenes a la filosofía platónica son de especial interés para Deleuze ya que se dirigen contra la noción de Idea. Al igual que las críticas estoicas, están dirigidas contra la autonomía de la esencia por fuera de los cuerpos, lo que sirve a Deleuze para sostener otra manera diferente de entender las "esencias" como inmanentes a los hechos en la noción de acontecimiento que propondrá como nombre del "sentido" (1969, 152-8, 13-21). Cuenta Laercio que un día, para burlarse de la definición platónica de "hombre” llevó un

10 Para un desarrollo más acabado de lo que implica esta provocación como proceso pedagógico véase Cordero (2013). 
pavo desplumado a sus discípulos diciendo que era un "bípedo implume" (VI, 40). Otra vez se paseaba en plena luz del día con una lámpara y al preguntarle alguien qué hacía respondió que buscaba "al hombre", mofándose así de la sustancialización platónica del individuo (VI, 41). Hay otra anécdota que refiere a una crítica contra la noción misma de Idea; dice Laercio que cuando Platón dialogaba sobre las ideas y mencionaba la «mesidad» y la «tazonez», dijo: «Yo veo una mesa y un tazón, pero de ningún modo la mesidad y la tazonez». Y él replicó: "Con razón, porque posees los instrumentos con los que se ven la mesa y el tazón, los ojos. Pero aquello con lo que se percibe la mesidad y la tazonez, la inteligencia, no la posees" 11 Y otra contra la noción de participación, en la que Diógenes ofrece a Patón compartir (metaskeîn) unos higos y cuando éste aceptó le dijo: "dije compartir, no devorar" (metáskheîn eipon, ou katarageîn) (DL VI, 25)

Deleuze repara especialmente en la anécdota en la que Diógenes Laercio relata que Diógenes defendía la antropofagia. "Ni siquiera le parecía impío el devorar trozos de carne humana, como ejemplificaba con otros pueblos." El interés de Deleuze radica en el trasfondo metafísico de la explicación que da Diógenes Laercio de por qué Diógenes defendía la antropofagia: "Incluso comentaba que, según la recta razón, todo estaba en todo y circulaba por todo. Así, por ejemplo, en el pan había carne y en la verdura pan, puesto que todos los cuerpos se contaminan con todos, interpenetrándose a través de ciertos poros invisibles y transformándose conjuntamente en exhalaciones" (VI, 73). Este texto habría estado escrito en una de las tragedias atribuidas a Diógenes, el Tiestes. ${ }^{2}$ Deleuze repara aquí en la vinculación con Crisipo, filósofo estoico. Trae a colación la idea de khrâsis que es, dice, la mezcla perfecta y líquida donde todo es justo $(1969,156) .{ }^{13}$

Deleuze afirma que Crisipo distingue entre dos tipos mezclas, las imperfectas y las perfectas. En las mezclas imperfectas los cuerpos se alteran mientras que en las mezclas perfectas permanecen inalterados y coexisten en todas sus partes. Es la unidad de las causas corporales entre sí la que define la mezcla perfecta en la que todo es justo y presente. Lo que a Deleuze le interesa destacar es cómo la idea de una causalidad corporal habilita un espacio en el que no hay moral, toda mezcla es posible, no hay incesto ni canibalismo porque todos los cuerpos se penetran mutuamente. La norma se aplica a los cuerpos ya delimitados, pero no al fondo del que todo surge.

No obstante lo expresado por Deleuze, en rigor, según el fragmento conservado de Estobeo en el que éste relata la cuestión de la mezcla, Crisipo distinguía entre cuatro tipos de mezcla: la yuxtaposición (paráthesis), que es la suma de cuerpos, como los montones

11 Esta anécdota es similar a la que se relata sobre Antístenes, quien le decía a Platón "veo el caballo pero no la caballeidad". Véase 2.2.

12 Aunque hay dudas acerca de la atribución del texto. Ya Diógenes Laercio mismo pone en duda que Diógenes haya sido el autor del Tiestes. Pero además, hay varios debates modernos y contemporáneos que ponen en cuestión la atribución de estos enunciados a Diógenes. En primer lugar hay quienes ponen en duda que Diógenes haya escrito el catálogo de obras que Laercio refiere en VI, 80, como es el caso de Sayre, (2011) (Giannantoni, 1990: IV, 462-463). En segundo lugar, y en relación a las tragedias específicamente, hay quienes atribuyen este catálogo de obras a Diógenes el estoico. En tercer lugar, y en relación al Tiestes, el eco de este texto con la doctrina de Anaxágoras ha llevado a algunos, como Zeller (1920), a poner en duda la atribución del mismo a Diógenes. (Cf. Giannantoni: IV, 461- 484)

13 Como lo sostiene Giannantoni, se podría vincular el texto del Tiestes también con Anaxágoras y con la filosofía epicúrea (1990: IV, 480) 
de cereales por ejemplo; la mezcla (míxis) que es la mezcla o coextensión (anti-paréktasis) total de dos o más cuerpos que mantienen no obstante sus cualidades propias, como sucede con el fuego y el hierro al rojo o con nuestros cuerpos y sus almas; la mixtión (khrâsis) que es la coextensión recíproca total de dos o más cuerpos en el que cada uno conserva las cualidades que le son propias pero que sólo se aplica en el caso de los líquidos; y por último la fusión (sunkhusis) que es la composición de dos o más cuerpos que hace nacer una nueva cualidad (Cris. Fr. 401 [471 S.V.F]). ${ }^{14}$

Por otro lado está el pneûma, que es un hálito que se mueve a sí mismo (ídem). Todo lo que existe es pneûma y es éste el que admite los cuatro tipos de mezcla. El pneûma, que es todo lo que existe, es corpóreo. Ésta es una de las condiciones de la metafísica estoica que interesa particularmente a Deleuze: este hálito que se mueve a sí mismo y que constituye el fondo de toda mezcla y en el cual confluyen todas las causas $(1969,13-21)$.

Hasta aquí parecería entonces que nos encontramos mirando a las profundidades, sin embargo Deleuze sostiene que los estoicos y los cínicos son los filósofos de las superficies. Entiendo que se trata de lo siguiente: en tanto la mezcla de los cuerpos, el pneûma es el lugar de la auténtica causalidad, y es el lugar en el que valen todas las mezclas. El plano normativo queda relegado al plano de nuestra existencia concreta como cuerpos ya determinados en un todo cuya causalidad real desconocemos. Como veremos, este es el plano de los "incorporales" que vienen a jugar en el estoicismo el rol que las Ideas juegan en la filosofía platónica, a saber, el de las esencias. A diferencia de las Ideas, los incorporales son inmanentes a los cuerpos. Esto abre toda una dimensión para pensar el sentido en los términos en los que Deleuze desarrollará la noción en Lógica del sentido.

\section{Las superficies estoicas}

Uno de los rasgos principales que hace de la filosofía estoica un pensamiento novedoso es la tesis de que sólo lo corporal es real en un sentido estricto ya que sólo los cuerpos tienen poder causal. Esta base es la que hace de la ontología estoica una inversión de la filosofía platónica (también de la aristotélica) que postulaba no sólo que las Ideas son causas, sino que son las causas por excelencia. Esta tesis está acompañada de la compleja teoría de los incorporales (asómata).

El esquema metafísico general que propone el estoicismo toma posición respecto de una discusión de larga data respecto de la sede de la verdad..$^{15}$ Ya no se trata de concatenar lo real, el pensamiento y el lenguaje y establecer entre ellos relaciones de significación y simbolización, ${ }^{16}$ sino que se distinguen directamente los planos de tomándolos de manera independiente. La gnoseología descansa sobre la relación entre dos cuerpos: lo que existe, tò tynchánon, y el lenguaje, pensado en este punto como la voz articulada y por tanto material. La novedad estoica será desplegar la afirmación de un tercer elemento ya no corporal sino incorpóreo que conecta los cuerpos y tiene el carácter de algo que "coexiste" con nuestro pensamiento y porta, precisamente, el significado.

14 Nos basamos en la edición de Von Arnim, (1903) y la traducción de Campos Daroca \& Nava Contreras (2006)

15 El pasaje de Sexto Empírico (M VIII 11-12; FDS 67 = SVF II 166) que explica este esquema resulta en buena medida un rediseño del inicio del tratamiento aristotélico en el De Interpretatione

16 Sobre este esquema véase Whitaker (1996) y Bordoni (1994). 
Aquí es donde cobra importancia la diferencia de los estos planos. En el plano de los cuerpos, estamos frente a casos de existencia, que los estoicos no mientan con la noción de eînai sino con la de hypárchein, verbo de larga data en la lengua griega que ya usaba Aristóteles con el sentido de existencia pero de modo secundario. Para los estoicos, el hypárchein será el modo de la existencia plena y autónoma, la de los cuerpos que entran en relación directa y están sujetos a la legalidad de acción y pasión..$^{17}$ Los incorpóreos no existen sino que subsisten (hyphistánai), es decir que les toca un tipo de estado en algún sentido parasitario y dependiente respecto de los cuerpos. ${ }^{18}$ En el caso del lektón, incorpóreo portador del significado, esta dependencia asegura una continuidad y calidad de representación respecto del cuerpo que lo aloja.

Los significados son precisamente el material con que opera la mente para tratar de construir un modelo microcósmico del mundo que nos circunda. El lenguaje enuncia nociones acerca de las cosas, a lo cual responde la categoría de lektón, 'enunciable', adjetivo verbal conformado precisamente sobre el verbo légo, literalmente 'lo que se puede decir'. Además del lektón la lista que ofrece Sexto Empírico $(M, 10.218)$ agrega tres incorpóreos más: vacío, lugar y tiempo. Así como el lektón resulta fundamental para explicar el mecanismo de significación y el de procesamiento mental en general, los otros casos nos enfrentan igualmente a nociones centrales de otros ámbitos de la doctrina, especialmente la física ${ }^{19} \mathrm{En}$ este sentido, el carácter derivado de los incorpóreos no constituye un disvalor, como señala M. Boeri cuando sostiene que las lecturas que atribuyen a los incorporales una realidad secundaria o inferior son engañosas y no son fieles a la posición estoica. Los incorporales son esenciales para dar cuenta del plano de los cuerpos y ambos planos (el de los cuerpos y el de los incorporales) son complementarios en el sentido de que no pueden existir el uno sin el otro (Boeri, 2001).

Esta complementariedad es lo que explica el peculiar andamiaje metafísico del estoicismo, que no conforma una ontología, lo cual supone, como en el caso de Aristóteles, que la noción de ser es considerada como el género supremo, sino que constituye más bien una "algología", dado que por sobre el cuerpos existentes e incorpóreos subsistentes se ubica en la cima y máxima en amplitud la noción de $t i$ (algo), que abarca cuerpos e incorpóreos, haciendo del cosmos "algo", antes que entidad. ${ }^{20}$

Los cuerpos y los incorporales no son de status ontológicos incompatibles, sino que los distintos tipos de incorporales, a saber, tiempo, espacio, vacío y enunciable, se complementan de manera particular con el plano corporal. Clemente, por ejemplo, sugiere que el tiempo está implicado en el proceso de aprendizaje ya que tiene una duración, esto implica que podemos afirmar que tiene una función causal. En tanto incorporal, es causa, pero en el

17 Sexto Empirico, Contra los profesores, IX.11 (SVF, I.301; FDS, 130): “(...) los de la Stoa, al decir que hay dos principios, dios y materia sin cualidad, han supuesto que la divinidad actúa y que la materia, en cambio, padece y es transformada".

18 Sobre este punto, véase Goldschmidt (1972, 331-345), Graeser (1971, 299-305) y Gourinat (2009, 23-40).

19 Sobre la noción de lektón véase Drozdek (2002, 93-104) y Sedley (1985, 87-92).

20 Véase Séneca (Cartas, 58.13-15; SVF, II.332; FDS, 715). Sobre la “ontología” estoica véase Aubenque, (1991, 365-385), Bronowski, (2007, 71-81), Brunschwig, (1988, 19-127), Coloubaritsis (2005, 187-211) y Crivelli (2007, 89-122). 
sentido de "condición necesaria" 21 que, no es causa en el sentido estricto porque corresponde al plano de los incorporales y no al de los cuerpos.

El tiempo no es un mero contenido mental separable de los existentes, sino que mide los movimientos en series ordenadas. Ni siquiera la propia causalidad podría ser comprendida sin este ordenamiento cronológico. Pero además, si bien el tiempo, como todo incorporal, sólo subsiste, en este caso son pasado y futuro los que subsisten, el presente en cambio, existe. Los estoicos desarrollaron el concepto de "estar presente", o "estar ahí". Mientras pasado y presente subsisten (hyphestánai), el presente está ahí (hypárkhein).

En el caso de los decibles, enunciables o lektá, la interdependencia se da porque el significado es el que establece las relaciones lógico-lingüísticas que nos permiten categorizar los objetos. A su vez, los significados son expresados en palabras y las palabras, tanto en su versión gráfica, como en su versión sonora, son cuerpos. Los estoicos establecen una diferencia entre prophéresthai y légetai, si bien los estados de cosas (tà prágmata) son dichos (légetai), las palabras, como sonidos son proferidas (prophéresthai).

Los lektá cumplen una función de particular importancia en el ámbito de la psicología de la acción estoica. Ésta tiene una estructura que consta de tres pasos: la presentación (phantasía), el asentimiento (sunkatáthesis) y el impulso (hormé). La presentación es, en el caso de los humanos, articulada en el lenguaje; el asentimiento, que sigue a la presentación consiste en aceptar la presentación como verdadera, es decir, en dar el consentimiento a la proposición que expresa el contenido de la presentación una vez dados estos dos pasos, la afirmación se convierte en impulso para la acción. ${ }^{22}$ En la medida en que articulamos lo real en el lógos y esta articulación es indispensable para la comprensión y por lo tanto para la acción, no puede decirse que el plano del significado no sea irreal, es algo. Es por ello que el término más general en el lenguaje estoico, como vimos, es $t i$, "alguna cosa", que comprende, tanto a los cuerpos como a los incorporales.

Si tenemos en cuenta que lo corpóreo es, para los estoicos, el rasgo esencial de lo existente (tò ón) y que sólo los cuerpos son susceptibles de actuar o recibir una acción, y sólo lo que es activo o pasivo es propiamente existente, cualquier cosa que no tenga estas características es, forzosamente, inexistente y, dado que sólo los cuerpos tienen esta característica, debe ser, por lo tanto, incorporal. La mezcla entre cuerpos o pneûma es la causa por excelencia, en virtud de su movimiento cohesionante.

Según Deleuze, en el sistema estoico tanto acción y pasión son determinados por las mezclas entre cuerpos, en cuyo límite "hay una unidad de todos los cuerpos en función de un Fuego primordial donde se reabsorben y a partir del cual se desarrollan siguiendo su respectiva tensión" $(1969,13)$. En efecto, en este enfoque se recupera el elemento de unidad que los estoicos pretenden dar al cosmos, de modo tal que nada queda al margen y por tanto

21 Clem. Stromata 8.9.25.4.1: "Pues todas las causas pueden ser mostradas en orden en el caso del aprendiz. El padre es la causa procatárctica del aprendizaje, el maestro es la causa sinéctica, y la naturaleza del aprendiz la causa cooperante, y el tiempo sostiene la relación de la causa sine qua non." La diferencia entre causa y condición necesaria consiste, entonces, en la relación inversa a la que se da según Platón. El tiempo, en tanto incorporal, tiene un rol en el proceso, pero es el de ser condición para que éste se efectúe. La causa, propiamente hablando, es el maestro, es decir, un cuerpo.

22 Para un análisis detallado de los tres pasos y de la función de la reflexión y el juicio (krisis) como especificidad de la naturaleza humana véase Salles (2006, 87-111) 
en riesgo de ser inaprehensible. El elemento fundamental para esto es el pneûma, término asociado con la respiración, a menudo traducido por 'soplo', 'hálito' o 'espíritu' que recorre y cohesiona todas las cosas. El pneûma es el hálito "... por el que todo se mantiene unificado y estable y en relación consigo mismo (sympathés)" (Alejandro de Afrodisia, 1-218). Frente a esta fuerza, la materia es pasiva (tò páskhon), pero ambos son, igualmente, cuerpos. El pneûma se manifiesta de distinto modo en distintos niveles de la realidad: en las piedras como héxis, en las plantas como phúysis y en los animales como psukhé. Se trata del mismo pneûma en distintos grados de tensión (tónos), lo cual refuerza la idea de que una misma lógica explica todos los ámbitos del cosmos y legitima la pretensión de que las tres partes de la doctrina están conectadas en múltiples puntos. ${ }^{23}$ En el caso particular de la psukhé, el tono también varia con sus estados, por ejemplo, el dolor es una contracción (systolé) y el placer una expansión (éparsis) del alma. Cabe señalar que el alma, para los estoicos, es también un cuerpo, es pneûma cálido, un requisito esperable, dado que sôma y psukhé deben tener una naturaleza similar dado que ejercen acción recíproca uno sobre otro. Si no fueran de naturaleza corpórea no podrían entrar en contacto. ${ }^{24}$

Las superficies quedan asociadas en el estoicismo al lugar que ocupa la temática de los incorporales que Deleuze toma como rasgo principal y que revela una importancia central dentro de la doctrina ya que muestra la distancia respecto de la metafísica del platonismo. No es menor, por otra parte, que el universo del estoicismo ofrece una complejidad y una multiplicidad de planos que invita al diálogo con la posición de Deleuze, anclada firmemente en el clima de discusiones de la contemporaneidad, pero asociada a la vez con las derivas antiguas del estoicismo.

\section{Consideraciones finales}

Mediante el recorrido a través de las fuentes y de los comentarios de los especialistas creemos haber mostrado que, si bien es cierto que la lectura de Deleuze presenta algunas tergiversaciones --especialmente en el marco del sistema estoico--, aplica de manera válida el criterio topológico-nosológico del que se vale para responder a la pregunta que se plantea, a saber, ¿quién piensa en filosofía? La responde, además, de una manera novedosa valiéndose de estos sistemas de pensamiento antiguo.

Luego de haber trazado un recorrido por las alegorías de República hemos constatado que el juego conceptual que Platón establece por medio del uso alegórico de los tópoi, identificando el arriba con el plano noético y el abajo con el plano sensible, concuerda con el diagnóstico deleuziano del ascensionismo psíquico. Dado que el proceso implica el bajar nuevamente al plano de las sombras, también concuerda con el diagnóstico que equipara el platonismo con el movimiento maníaco-depresivo. Asimismo, el interés presocrático por

23 Véase Diógenes Laercio, VII.39-42 (SVF, I.41; FDS, 189).

24 La naturaleza pneumática es descripta por Calcidio como un aliento natural (spiritus naturalis) que equipara con el alma (In Tim. 220; SVF II.879). La afirmación de que el alma es corpórea tiene implicancias sobre la ética estoica ya que todo aquello que la modifica o se modifica con ella son también de carácter corpóreo. Las disposiciones virtuosas de un agente racional también son entendidas como casos de una buena tensión (eutonía) del pneûma. Véase Boeri (2009). 
la phúsis, representado por la sandalia de Empédocles que emerge del volcán configura en contrapunto de las alturas platónicas que Deleuze asimila a la trascendentalidad de la Idea.

Pero el interés que despierta la lectura deleuziana consiste en su apropiación de las filosofías cínica y estoica para su propia concepción de la imagen del filósofo. el pensador debe tener su mirada puesta en la superficie. Como hemos visto, en el caso de Diógenes de Sínope, se basa en la concepción de la tarea del filósofo como la crítica a los valores vigentes. Ésta puede leerse como una perversión del orden moral, si tenemos en cuenta que la etimología de la palabra no solo indica corrupción sino también un trastocamiento, una inversión. Como hemos podido demostrar mediante el análisis de las fuentes, en la vida de Diógenes las superficies son las superficies de la pólis. La mirada del filósofo cínico no está puesta en la búsqueda de fundamentos sino en la transformación de la conducta del otro mediante el uso performático de la paradoja. Vida y obra filosófica no se distinguen, el cambio debe ser generado por la conducta del propio filósofo.

En el caso del estoicismo, no importan tanto las anécdotas como el sistema filosófico. Aunque Deleuze alude a algunas anécdotas de la vida de Crisipo de Solos, creemos habar mostrado que, en rigor, las superficies estoicas deben ir buscarse a la teoría de los incorporales. Este concepto, del que Deleuze se apropia para su teoría del acontecimiento, coloca en las superficies aquello que Platón colocaba en las alturas de la Idea y que los presocráticos colocaban en las profundidades de la phúsis, a saber, el sentido. Como ha quedado demostrado mediante el análisis de las fuentes, la noción de incorporal reemplaza a la Idea, despojando el plano eidético de su carga causal. Pero lo más importante es ver que incorporales y cuerpos cohabitan en el mismo plano, dando por tierra con el plano de trascendencia que inauguraba la Idea platónica.

Deleuze traslada de este modo los elementos de estos sistemas de pensamiento antiguo a un espacio de controversia actual. Los estoicos y los cínicos nos proveen del arquetipo del pensador que necesitamos hoy para revertir los efectos del platonismo. El filósofo actual debe posar su mirada en las superficies, como lo hacían Diógenes y Crisipo entonces. El problema de la imagen del filósofo es una de las aristas del problema más general de la inversión del platonismo, que tiene por objeto revertir los efectos que ha tenido su idealismo congénito en la tradición filosófica.

\section{Bibliografía}

Antonioli, M. (1999). Deleuze et l'histoire de la philosophie. Paris: Editions Kimé.

Aubenque, P. (1991). “Une Occasion Manquée: La Genèse Avortée De La Distinction Entre L' 'Étant' Et Le 'Quelque Chose.'” In P. Aubenque (ed.) Études Sur Le Sophiste De Platon (pp. 365-385). Napoli: Bibliopolis.

Aubenque, P. (1992). "Oui et non" en Cassin, B. (ed) Nos grecs et leurs modernes. Paris, Éditions du seuil, pp. 17-37. [“Sí y no", en B. Cassin (ed.) (1994), Nuestros griegos y sus modernos. Estrategias contemporáneas de apropiación de la antigüedad (pp. 155-168) (traducción española I. Agoff). Buenos Aires: Manantial.]

Berti, E. (1975). Studi aristotelici. L' Aquila: L. U. Japadre.

Boeri, M. D. (2001). "The Stoics on bodies and incorporeals". The Review of Metaphysics, $723-752$. 
Boeri, M. D. (2009). "Causa sinéctica y actividad neumática en los estoicos”. Revista Latinoamericana de Filosofía, 35(1), 5-34.

Bordoni, G. S. (1994). Linguaggio e realta in Aristotele (1. ed edition). Roma: Laterza.

Bronowski, A. (2007). “The Stoic View on Universals”. Documenti E Studi Sulla Tradizione Filosofica Medievale, 18, 71-87.

Brunschwig, J. (1988). "La Théorie Stoïcienne Du Genre Suprême Et L'ontologie Platonicienne.” In J. Barnes y M. Mignucci (eds.) Matter and Metaphysics. Fourth Symposium Hellenisticum (pp. 19-127). Napoli: Bibliopolis.

Brunschwig, J. (1992). “Oui et non” en B. Cassin (1992), pp. 37-67.

Burnet, J. (1902). Platonis opera; Oxford: Clarendon Press.

Campos Daroca, F. J., \& Nava Contreras, M. (2006). Crisipo de Solos, Testimonios y Fragmentos (Vol. I, II). Madrid: Gredos.

Canavera, J. (2012). Lo que significa "hacer" historia de la filosofía: Deleuze y la cuestión del método. Daimon Revista Internacional de Filosofía, (55), 21-37.

Cherniavsky, A., \& Jaquet, C. (Eds.). (2013). L' art du portrait conceptuel - deleuze et l'histoire de la philosophie. Paris: Classiques Garnier.

Coloubaritsis, L. (2005). "Les Structure Hénologiques Dans Le Stoïcisme Ancien”. In G. Romeyer Dherbey, y J.B. Gourinat (eds.) Les Stö̈ciens (pp. 187-211). Paris: Vrin.

Cordero, N. L. (2013). "El filosofo cínico". Boletín de Estética, 23, 29-42.

Crivelli, P. (2007). "The Stoics on Definitions and Universals". Documenti E Studi Sulla Tradizione Filosofica Medievale, 18, 89-122.

Deleuze, G. (1968). Différence et Répétition. Presses Universitaires de France.

Deleuze, G. (1969). Logique du sens. Editions de Minuit.

Dorandi, T. (1991). "La Politeia de Diogène de Sinope et quelques remarques sur sa pensée politique". In Goulet-Cazé, M. O. y Goulet, R. Le cynisme Ancien et ses prolonguements (pp. 57-68). Paris: Presses Universitaires de France.

Drozdek, A. (2002). "Lekton. Stoic Logic and Ontology". Acta Antiqua. Academiae Scientiarum Hungaricae, 42, 93-104.

Giannantoni, G. (1990). Socratis et Socraticorum reliquiae (Elenchos) (Vol. 4). Bibliopolis.

Giannantoni, G. (1991). “Antistene fondatore de la scuola cinica?” In Goulet-Cazé, M. O. Goulet, R. Le cynisme Ancien et ses prolonguements. Paris: Presses Universitaires de France.

Ginoux, I. (2005). "Platon.” In Aux sources de la pensé de Gilles Deleuze (S. Leclerc, Vol. 1, pp. 155-160). Paris: Sils Maria Éditions.

Goldschmidt, V. (1972). "Hyparxein Et Hyphistanai Dans La Philosophie Stoicienne.” Revue des Études Grecques, 331-345.

Gourinat, J. (2009). "Épistémologie, rhétorique et grammaire.” In J.B. Gourinat y J. Barnes (eds.) Lire Les Stoïciens. Paris: Presses Universitaires France.

Graeser, A. (1971). “A Propos Hyparkein Bei Den Stoikern”. Archiv Für Begriffgeschichte, 15, 299-305.

Hicks, R. D. (1972). Lives of Eminent Philosophers. Diogenes Laertius (First ed. 1925). Cambridge: Harvard University Press.

La Planche, J., \& Pontalis J. B. (1996). Diccionario de Psicoanalisis (Tra edition). Barcelona: Paidos Iberica, Ediciones S. A. 
Macintyre, A. (1984) “The relationship of philosophy to its past" en R. Rorty, Q. Skinner, J.B. Scheenwind (eds.) Philosophy in History: essays on the historiography of philosophy. Cambridge, Cambridge University Press.

Marsico, C. T. (2010). Zonas de tension dialogica. Libros del Zorzal.

Mársico, C. T., \& Divenosa, M. (2005). Platón. Republica. Buenos Aires: Losada.

Salles, R. (2006). Los Estoicos y el problema de la libertad. Mexico: UNAM.

Sayre, F. (2011). Diogenes of Sinope: A Study of Greek Cynicism (1st ed. 1939). Literary Licensing, LLC.

Schofield, G. S. K. E. R. (1957). The Presocratic Philosophers: A Critical History with a Selection of Texts by G. S. Kirk. Cambridge University Press.

Sedley, D. (1985). "The Stoic Theory of Universals.” In Epp, Ronald H. (ed.) Recovering the Stoics (Memphis University Press, pp. 87-92). Memphis.

Sellars, J. (2007). Gilles Deleuze and the history of philosophy. British Journal for the History of Philosophy, 15(3), 551-560.

Von Arnim, J. (1903). Stoicorum veterum fragmenta. Leipzig: Teubner.

Whitaker, C. (1996). Aristotle's De Interpretatione: Contradiction and Dialectic. Oxford: Oxford University Press.

Wieland, W. (1988). "La actualidad de la Filosofía antigua." Méthexis, 1, 3-16.

Wolff, F. (1992) "Trios. Deleuze, Derrida, Foucault, historiens du platonisme" en Cassin, B. (ed) Nos grecs et leurs modernes. Paris, Éditions du seuil.

Zeller, E. (1920). Grundriss der Geschichte der griechischen Philosophie. Leipzig : O. R. Reisland.

Zourabichvili, F. (2003) Le vocabulaire de Gilles Deleuze, Paris: Ellipses. 